\title{
VEIKSNIAI, TURINTYS İTAKOS LAIKINOJO NEDARBINGUMO TRUKMEI LIETUVOJE
}

\author{
Aušra Survilaitė \\ Valstybinio socialinio draudimo fondo valdybos Vilniaus skyrius \\ Laisvès pr. 28, LT 04540 Vilnius, Lietuva \\ El. paštas a_survilaite@yahoo.com
}

\begin{abstract}
Aldona Gaižauskienè
Vilniaus kolegija, Saltoniškių g. 58, LT 08105 Vilnius

Mykolo Romerio universitetas, Ateities g. 20, LT 08303 Vilnius, Lietuva

El. paštas aldona.gaizauskiene@gmail.com

Pateikta 2014 m. rugpjūčio 25 d., parengta spausdinti 2014 m. spalio 12 d.
\end{abstract}

doi:10.13165/SPV-14-2-7-08

\section{Santrauka}

Straipsnio tikslas - nustatyti laikinojo nedarbingumo trukmei įtakos turinčius veiksnius Lietuvoje pagal K. Alexandersono ${ }^{1}$ (1998) pasiūlyta metodika nacionaliniame, visuomeniniame ir individualiame nedarbingumo organizavimo lygmenyse. Tyrimui naudoti 1991-2012 m. Valstybinio socialinio draudimo fondo valdybos ir Lietuvos statistikos departamento duomenys.

Nacionaliniam nedarbingumo organizavimo lygiui priskiriama darbdavio ir darbuotojo darbo sutarties sąlygu apibrėžimas, socialinio draudimo sistemos, ligos išmoku organizavimas ir sveikatos priežiūros teisinis reglamentavimas. Apžvelgus laikinojo nedarbingumo trukmés pokyčius 1991-2012 m. ir nedarbingumo kompensavimo teisinio reglamentavimo kitimus, nustatytos šiu dviejų veiksnių sasajos. Iš kitu keturiu nagrinètu veiksniu tik vidutinè metinè temperatūra turèjo patikimos itakos nedarbingumo trukmei. Visuomeniniam lygmeniui priskiriami su darbo aplinka bei bendruomene susije veiksniai. Nagrinèti keturi veiksniai. Patikimos sasajos buvo nustatytos su disponuojamomis namu ükio pajamomis ir su sveikatos priežiūros ịstaigu skaičiumi. Individualiam laikinojo nedarbingumo lygmeniui priskiriamos asmens charakteristikos. Iš triju veiksnių, nagrinètu šiame lygmenyje, išsilavinimas ir santuoku skaičius patikimai turejjo įtakos nedarbingumo trukmei.

Alexanderson, K. Sickness absence: a review of performed studies with focused on levels of exposure and theories utilized. Scandinavian Journal of Social Medicine. 1998, 4(26): 241-249. 
Veiksniu, turinčiu įtakos laikinajam nedarbingumui, nustatymas gali suteikti naudingos informacijos socialines politikos formuotojams, vykdytojams bei darbdaviams, gerinant laikinojo nedarbingumo kontrolę Lietuvoje.

Reikšminiai žodžiai: laikinasis nedarbingumas, socialinis draudimas, nacionaliniai veiksniai, visuomeniniai veiksniai, individualūs veiksniai.

\section{Ivadas}

Socialinė apsauga suprantama kaip valstybės ir privačių subjektų, kurių veiklą reglamentuoja valstybè, teikiama materialinè parama ar socialinès paslaugos asmenims, kurie susidūrè su socialine rizika ${ }^{2}$. Socialinis draudimas - tai socialinès apsaugos sistemos dalis, kuri yra finansuojama specialiomis įmokomis ir iš kurios mokamos socialinès išmokos ${ }^{3}$. Svarbus socialinès teisinès valstybès efektyvaus funkcionavimo ir stabilumo garantas yra solidarumas, kuris padeda įveikti socialinę įtampą, kylančią tarp valstybès ir visuomenès ${ }^{4}$.

Valstybinio socialinio draudimo įstatymas ${ }^{5}$ nustato socialinio draudimo santykių pagrindus - draudimo rūšis, draudžiamų asmenų kategorijas, valdymo sistemos principus bei struktūrą, jos subjektų teises, pareigas ir atsakomybę. Lietuvoje skiriamos penkios socialinio draudimo rūšys: pensijų, ligos ir motinystės, nedarbo, nelaimingų atsitikimų darbe ir profesinių ligų bei sveikatos draudimas. Draudimas remia bei padeda ịveikti pagrindines socialines rizikas, visuomenès grèsmes ir pavojus, tokius kaip senatvè, negalia, mirtis, liga ar trauma, nedarbas, susiklosčiusi sunki situacija šeimoje, nepriteklius ar skurdas.

Šiame straipsnyje plačiau nagrinèsime ligos ir motinystès socialinio draudimo dalị - laikinąji nedarbingumą. Laikinasis nedarbingumas - tai laikotarpis, kai asmuo dèl su sveikata susijusių priežasčių negali dalyvauti profesinejje veikloje. Laikinojo nedarbingumo sąvoka apima ne tik ligos ar traumos laikotarpi, tačiau ir asmens santykius su sveikatos priežiūros įstaiga, socialiniu draudimu ir darbdaviu. Sprendimai dèl teisès ị išmokas ligos atveju turi didelę įtaką asmens gyvenimo kokybei ir visuomenei. $2013 \mathrm{~m}$. Valstybinio socialinio draudimo fondo valdybos (VSDFV) biudžeto priskaičiuotos piniginès išlaidos buvo $11 \mathrm{mlrd}$. $167,4 \mathrm{mln}$. Lt, o išlaidos ligos ir motinystès socialinio draudimo išmokoms sudarè net 10,4 proc. visų išlaidų ${ }^{6}$. Socialinio draudimo pašalpų ir kompensacijų išmokų struktūroje didžiausią dalị sudaro ligos pašalpos, todèl siekiant racio-

Guogis, A., et al. Lietuvos politiniu partiju samprata apie socialinę apsauga. Vilnius: Eugrimas, 2000. Guogis, A. Dèl socialinès politikos modelio. Politologija. 2002, 4 (28): 75-94.

4 Bieliauskaitè, J. Solidarumo vaidmuo socialineje teisinèje valstybèje. Socialiniu mokslu studijos. 2009, 1(1): 79-94.

5 Lietuvos Respublikos valstybinio socialinio draudimo ịstatymas. Valstybès žinios. 1991, Nr.17-447; 2004, Nr. IX-2535, Nr. 171-6295.

6 VSDFV pranešimai spaudai [interaktyvus]. [žiūrèta 2013-10-12]. <http://www.sodra.lt/index. php?cid=182\&new_id=24609\&page_nr=>. 
nalaus VSDFV biudžeto lèšų naudojimo ypač svarbų vaidmenį atlieka laikinojo darbingumo kontrolè, kuri neleidžia piktnaudžiauti VSDFV lěšomis?

Siekiant sukurti visuomenès poreikius ir lūkesčius atitinkančią socialinę apsaugą tikslinga ịvardinti veiksnius, nuo kurių priklauso nedarbingumo politikos formavimas. Priemonių, sąlygų ar veiksnių sąsajų su laikinuoju nedarbingumu nustatymas gali ne tik prisideti prie sistemos tobulinimo, bet ir nurodyti labiausiai pažeidžiamas kryptis bei grupes, kurioms reikia daugiau dèmesio, kontrolès ir pokyčių. Straipsnio tikslas - nustatyti veiksnius, turinčius įtakos laikinojo nedarbingumo trukmei Lietuvoje nacionaliniame, visuomeniniame ir individualiame nedarbingumo organizavimo lygmenyse.

Tyrimo metodika. Veiksnių, turinčių ịtakos laikinojo nedarbingumo trukmei Lietuvoje, nustatymui pasirinkti K. Alexandersono ${ }^{8}$ (1998) pasiūlyti veiksnių atrankos kriterijai ir jų grupavimas. Atsižvelgiant ị tai, kas suponuoja, reguliuoja ir kontroliuoja situaciją, visi veiksniai suskirstyti $\underset{\text { }}{\text { tris }}$ pagrindinius lygius: nacionalinị, visuomeninị ir individualų. Nacionaliniam lygmeniui priskirti klimatas, pramonès plètra, nedarbo lygis, visuomenès požiūris, darbdavio ir darbuotojo darbo sutarties sąlygų apibrèžimas, socialinio draudimo sistemos, ligos išmokų organizavimas ir sveikatos priežiūros teisinis reglamentavimas. Visuomeniniam lygmeniui priskirtos darbo aplinkos sąlygos: reikalavimai ir organizavimas, fiziniai pavojai, darbovietės dydis, sektorius bei pobūdis, personalo politika ir stresas, darbo krūvis, darbo užmokestis ir kontrolè. Individualiam lygmeniui priskirti asmens charakteristikos savybès, asmens amžius, subjektyvus sveikatos vertinimas ir esama situacija, gyvenimo būdas, išsilavinimas, šeiminè padètis bei santykiai, asmeniniai gebejjimai, gyvenimo sąlygos ir būdas, žalingi ịpročiai, psichinè būklè bei motyvacija ir požiūris, elgesio ydos, tokios kaip sergamumo simuliavimas.

Tyrimui naudoti VSDFV ir Lietuvos statistikos departamento svetainèje paskelbti duomenys, apimantys 1991-2012 m. laikotarpi ir atitinkantys K. Alexandersono pasiūlytus veiksnius. Atlikta statistinè kiekybinių duomenų analizè. Laikinojo nedarbingumo ryšiams tarp veiksnių nustatyti priklausomu kintamuoju buvo pasirinktas apmokètų laikinojo nedarbingumo dèl ligos dienų skaičius vienam apdraustajam. Nepriklausomi kintamieji buvo veiksniai, kurie gali turèti ịtakos laikinojo nedarbingumo pokyčiams. Kintamųjų ryšiui nustatyti apskaičiuotas Pirsono (Pearson) tiesinès koreliacijos koeficientas. Pagal pasirinktą reikšmingumo lygmenį kiekvienam atvejui tikrinta hipotezė nustatyto ryšio tinkamumui patvirtinti arba atmesti, duomenys patikimi, kai nustatoma, $\operatorname{kad} \mathrm{p}<0,1$.

Predkelienè, R. Asmens poreikiu samprata, klasifikavimas ir atspindejjimas socialinès apsaugos teiseje. Magistro darbas. Vilnius: Mykolo Romerio universitetas, 2007.

Alexanderson, K., supra note 1, p. 241-249. 


\section{Tyrimo rezultatai ir aptarimas}

\section{Nacionalinio lygmens veiksniai}

Daugelyje šalių socialinio draudimo teisinis reglamentavimas yra glaudžiai susijęs su laikinuoju nedarbingumu. Iki 2006 m. 158 pasaulio šalys pripažino mokamų laikinojo nedarbingumo atostogų svarbą ir tik 18 šalių nebuvo teisinio reglamentavimo dèl teisès nedirbti ligos atveju ir gauti pajamas už ši laikotarpi $i^{9}$. Laikinojo nedarbingumo išmokų kompensavimo problema ypač aktuali Norvegijoje. Ji organizuojama pagal nacionalinę draudimo sistemą. Valstybinio socialinio draudimo sistema valdo apie 30 procentų visų sektoriaus pajamų ${ }^{10}$. Autoriai H. T. Hansenas ir T. Ingebrigtsenas savo darbuose nurodo, kad pagal Norvegijoje galiojančią sistemą išmokos dèl ligos sudaro 100 procentų asmens pajamų ${ }^{11}$. Pirmosios 16 nedarbingumo dienų apmokamos darbdavio lèšomis, tolesnis laikotarpis finansuojamas iš nacionalinès draudimo sistemos. Tikètina, jog šimtaprocentinis nedarbingumo apmokejjimas yra vieno aukščiausių laikinojo nedarbingumo lygių Europoje priežastis.

Apžvelgiant padètị Lietuvoje matyti, kad 1991-2012 m. laikino nedarbingumo rodiklis, vertinant ji apmokètų ligos dienų skaičiumi vienam apdraustajam, kito (žr. 1 pav.).

\section{Lietuvos laikinojo nedarbingumo pokyčiai}

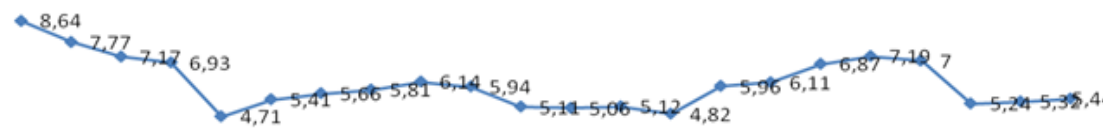

1991199219931994199519961997199819992000200120022003200420052006200720082009201020112012

Šaltinis: sudarytas autorių pagal VSDFV duomenis ${ }^{12}$

1 pav. Apmokètų laikinojo nedarbingumo ligos dienų skaičius vienam apdraustajam Lietuvoje 1991-2012 m.

$9 \quad$ Earle, A.; Ayanian, J. Z.; Heymann, J. Work resumption after newly diagnosed coronary heart disease: findings on the importance of paid leave. Journal of Women's Health. 2006, 4(15): 430-441.

10 Hansen, H. T.; Ingebrigtsen T., Social Class and Sickness Absence in Norway. Acta Sociologica [interaktyvus]. 2008, 51: 309-327 [žiūrèta 2013-10-12]. <http://asj.sagepub.com.skaitykla.mruni. eu/content/51/4/309.full.pdf+html>.

11 Ibid.

12 Valstybinis socialinis draudimas: statistiniai duomenys [interaktyvus]. 2012 [žiūrèta 2013-12-16]. $<$ http://www.sodra.lt/get.php?f.24143>. 
Didžiausias dienų skaičius užfiksuotas $1991 \mathrm{~m}$. (8,64 dienos), o mažiausias 1995 m. (4,71 dienos). Šiuo laikotarpiu padaryti laikinojo nedarbingumo teisinio reglamentavimo pokyčiai buvo reikšmingi. Vèliau laikinasis nedarbingumas vèl augo iki $2000 \mathrm{~m}$. Tad laikotarpiu nuo $1996 \mathrm{~m}$. iki $2000 \mathrm{~m}$. igyvendintos reformos nebuvo tokios veiksmingos, nes prisidejo prie nedarbingumo dèl ligos dienų skaičiaus augimo. Dar vienas laikotarpis, kurio metu laikinasis nedarbingumas kito neženkliai, buvo nuo $2001 \mathrm{~m}$. iki $2004 \mathrm{~m}$. Apmokètų dienų skaičiaus augimas ypač ženklus laikotarpyje nuo $2005 \mathrm{~m}$. iki $2008 \mathrm{~m}$. Po tokio kilimo nuo 2009 m. iki 2012 m. pastebimas nuoseklus mažejimas bei stabilumo palaikymas.

Siekdami suvokti vykusius pokyčius pirmiausia panagrinëjome, kaip kito laikinojo nedarbingumo teisinis reglamentavimas, kuris ir yra vienas pagrindinių laikinojo nedarbingumo kontrolès priemonių. Laikinojo nedarbingumo apmokéjimo sistemos pokyčiai atitinkamais laikotarpiais pateikti 1 lentelejje (žr. 1 lent.).

1 lentelè. Ligos pašalpos kompensavimo teisinio reglamentavimo raida

\begin{tabular}{|c|c|c|c|c|}
\hline Laikotarpis & Dienų skaičius & $\begin{array}{l}\text { Darbdavio atsa- } \\
\text { komybè (kompen- } \\
\text { suojamojo darbo } \\
\text { užmokesčio dalis) }\end{array}$ & $\begin{array}{l}\text { Valstybės } \\
\text { atsakomybè } \\
\text { (kompen- } \\
\text { suojamojo } \\
\text { darbo už- } \\
\text { mokesčio } \\
\text { dalis) }\end{array}$ & $\begin{array}{l}\text { Papildomi } \\
\text { reikalavimai }\end{array}$ \\
\hline \multirow{2}{*}{$\begin{array}{l}\text { Nuo } 1991 \mathrm{~m} \text {. } \\
\text { iki } 1995 \text {. }\end{array}$} & Nuo 1 iki 30 dienų & & $80 \%$ & \\
\hline & Nuo 31 dienos & & $100 \%$ & \\
\hline \multirow{3}{*}{$\begin{array}{l}\text { Nuo } 1995 \mathrm{~m} . \\
\text { vienuolika } \\
\text { ménesių }\end{array}$} & Nuo 1 iki 3 dienos & $>=50 \%$ & & \\
\hline & Nuo 4 iki 31 dienos & & $80 \%$ & \\
\hline & Nuo 31 dienos & & $100 \%$ & \\
\hline \multirow{3}{*}{$\begin{array}{l}\text { Nuo } 1995 \mathrm{~m} . \\
\text { pabaigos iki } \\
2000 \mathrm{~m} .\end{array}$} & Nuo 1 iki 2 dienos & $>=80 \%$ & & \\
\hline & Nuo 3 iki 31 dienos & & $80 \%$ & \\
\hline & Nuo 31 dienos & & $100 \%$ & \\
\hline \multirow{2}{*}{$\begin{array}{l}\text { Nuo } 2001 \text { m. } \\
\text { iki } 2002 \text { m. }\end{array}$} & Nuo 1 iki 2 dienos & $>=80 \%$ & $85 \%$ & \multirow{2}{*}{$\begin{array}{l}\text { Ivestas } \\
\text { draudimo stažc } \\
\text { reikalavimas - } \\
3 \text { menesiai per } \\
1 \text { metus arba } 6 \\
\text { menesiai per } 2 \\
\text { metus }\end{array}$} \\
\hline & Nuo 3 dienos & & & \\
\hline
\end{tabular}




\begin{tabular}{|c|c|c|c|c|}
\hline \multirow{2}{*}{$\begin{array}{l}\text { Nuo } 2002 \text { m. } \\
\text { iki } 2009 \text { m. }\end{array}$} & Nuo 1 iki 2 dienos & $\begin{array}{l}80 \%<=\text { Ligos pa- } \\
\text { šalpa }<=100 \%\end{array}$ & & \multirow{5}{*}{$\begin{array}{l}\text { Ivestas } \\
\text { draudimo stažo } \\
\text { reikalavimas - } \\
3 \text { ménesiai per } \\
1 \text { metus arba } 6 \\
\text { ménesiai per } 2 \\
\text { metus }\end{array}$} \\
\hline & Nuo 3 dienos & & $85 \%$ & \\
\hline \multirow{3}{*}{ Nuo 2009 m. } & Nuo 1 iki 2 dienos & $\begin{array}{l}80 \%<=\text { Ligos pa- } \\
\text { šalpa } \\
<=100 \%\end{array}$ & & \\
\hline & Nuo 3 iki 7 dienos & & $40 \%$ & \\
\hline & Nuo 8 dienos & & $80 \%$ & \\
\hline
\end{tabular}

Šaltinis: sudaryta autorių pagal A. Bartkaus, $2009^{13}$ darbo ir Lietuvos Respublikos Seimo paskelbtus duomenis ${ }^{14}$

Remiantis pateikta informacija akivaizdu, kad 1995 m. padaryti ligos pašalpos kompensavimo pakeitimai turejjo ịtakos dèl ligos dienų skaičiaus vienam apdraustajam mažejjimo. Ligos išmokų mokejjimo už tris pirmas dienas ịpareigojimas perleistas darbdaviui, sumažintos valstybės garantijos. Pakeitimai padaryti apdraustųjų asmenų nenaudai pasirodè per dideli, todẻl jau tų pačių metų pabaigoje padidinta darbdavio atsakomybé ir kompensuojamojo darbo užmokesčio dalis sudare iki 80 procentų vidutinio darbo užmokesčio, tačiau apmokamas laikotarpis sumažintas iki dviejų dienų. Tokia tvarka galiojo iki 2000 m., todèl ir ligos dienų skaičiaus kitimas vienam apdraustajam buvo neženklus. Nuo $2001 \mathrm{~m}$. įsigaliojusi pašalpos dẻl ligos kompensavimo tvarka sumažino ilgesnių laikinojo nedarbingumo periodų garantijas, ilgai sergantiems asmenims situacija tapo nepalanki. Tuo tarpu pagerejo trumpalaikio nedarbingumo situacija, nes nuo trečios laikinojo nedarbingumo dienos valstybès išmoka buvo lygi 85 procentų kompensuojamo darbo užmokesčio. Tad beveik neliko ribos tarp ilgalaikių, vidutinès trukmės ir trumpalaikių nedarbingumų. Be šio pakeitimo, apmokètų laikinojo nedarbingumo ligos dienų skaičiaus vienam apdraustajam mažejimui įtakos galèjo turèti įvestas draudimo stažo reikalavimas - 3 ménesiai per 1 metus arba 6 menesiai per 2 metus. Tarptautinè patirtis yra įvairi, pavyzdžiui, pagal Norvegijoje galiojančią socialinio draudimo sistemą visi darbuotojai, kurie dirbo bent 4 savaites iki susirgimo ir yra nedarbingi, turi teisę i i išmokas ligos atveju. Savarankiškai pranešti darbdaviui apie neatvykimą ị darbą dèl ligos leidžiama keturis kartus per metus, tačiau ne daugiau kaip trims dienoms. Apdraustas darbuotojas taip pat turi galimybę nedirbti, kai reikalinga sergančio

13 Bartkus, A. Senatvés pensijų ir laikinojo nedarbingumo išmokų finansinio tvarumo analizè. Daktaro disertacija. Vilnius: Vilniaus universitetas. 2009, p. 140-142.

14 Lietuvos Respublikos Seimo aktualios teisès aktų redakcijos laikotarpiu nuo $1991 \mathrm{~m}$. iki $2010 \mathrm{~m}$. [interaktyvus]. [žiūrèta 2013-12-16-2014-03-02]. <http://www.lrs.lt/>. 
vaiko priežiūra ${ }^{15}$. Igyvendinta reforma padidino ryši tarp ligos pašalpų išmokų ir imokų. 2002 m. patikslinta darbdavio atsakomybe - išmokos dèl ligos, mokamos darbdavio, negalëjo būti mažesnès nei 80 procentų ir didesnès nei 100 procentų kompensuojamo darbo užmokesčio. Tačiau tokie sistemos pokyčiai tikètina turejo įtakos trumpalaikių nedarbingumų daugèjimui, o kartu ir apmokètų laikinojo nedarbingumo dienų skaičiaus augimui. Itvertinus nedarbingumo didejjimą, 2009 m. padaryti sistemos pakeitimai teigiamai paveikè ir dèl ligos apmokètu dienų skaičiaus mažejimą. $2009 \mathrm{~m}$. sumažinti valstybès įsipareigojimai ypač paveikè trumpalaikius nedarbingumus, nes nuo trečios iki septintos laikinojo nedarbingumo dienos išmokos dèl ligos iš VSDFV biudžeto buvo lygios 40 procentų kompensuojamo darbo užmokesčio. Situacija dèl ilgalaikio nedarbingumo taip pat pasikeité, nes nuo aštuntos laikinojo nedarbingumo dienos valstybé ipareigota kompensuoti 80 procentų kompensuojamo darbo užmokesčio. Tokie staigūs pokyčiai apdraustų asmenų nenaudai 2010 m. nulèmé laikinojo nedarbingumo mažejimą. Remdamiesi pateiktu laikinojo nedarbingumo kompensavimo pokyčių aprašymu galime teigti, kad teisinio reglamentavimo pokyčiai tiesiogiai susiję su laikinojo nedarbingumo trukme. Tačiau yra ir kiti veiksniai, nuo kurių priklauso nedarbingumo pokyčiai Lietuvoje.

Nacionaliniu mastu laikinąji nedarbingumą veikia bendras ekonomikos lygis. Bendrąji ekonomikos lygi nusako bendrasis vidaus produktas (BVP). BVP yra rodiklis, kuriuo galima remtis vertinant šalies ekonomikos rezultatyvumą. BVP gali būti apibrèžiamas kaip per tam tikrą laikotarpi pagamintų šalyje galutinių prekių bei paslaugų rinkos vertè ${ }^{16}$.

Kitas labai svarbus šalies nedarbingumo lygiui įtakos turintis veiksnys - pramonės šakų plètra ${ }^{17}$. Kaip rodiklị, nurodantị pokyčius šioje srityje, panaudojome Lietuvos rinkos apdirbamosios gamybos užsakymų gaminti produkciją ir atlikti darbus indeksus procentais, kai nustatyta, kad $2005 \mathrm{~m}$. šis rodiklis lygus 100 procentų.

Kaip vienas iš pagrindinių nacionalinio lygmens veiksnių išskiriamas klimatas ir meteorologija. Klimato ịtakos tendencijai atspindèti panaudojome hidrometeorologijos tarnybos duomenis - vidutinę metinę temperatūrą laipsniais.

Dar vienas iš rodiklių yra darbo rinkos ir jègos organizavimas šalyje pagal amžių bei lytị. Šio rodiklio sąsajai su laikinojo nedarbingumo kitimu atspindèti naudojome užimtų, dirbančių gyventojų skaičių šalyje.

15 Hansen, H. T.; Ingebrigtsen T. Social Class and Sickness Absence in Norway. Acta Sociologica- 327 [interaktyvus]. 2008, 51: 309 [žiūrèta 2013-10-12]. <http://asj.sagepub.com.skaitykla.mruni.eu/ content/51/4/309.full.pdf + html $>$.

16 Bartkus, E. V. Smulkaus ir vidutinio verslo plètros prognozès Lietuvoje ekonominès krizès pradžioje. Ekonomika ir vadyba. 2010, 15.

17 Alexanderson, K., supra note 1, p. 241-249. 
2 lentelè. Nacionalinio lygmens veiksniai ir jų ryšys su laikinuoju nedarbingumu

\begin{tabular}{|c|c|c|c|c|c|}
\hline Metai & $\begin{array}{c}\text { Apmokètuc } \\
\text { laikinojo ne- } \\
\text { darbingumo } \\
\text { dienų dèl ligu } \\
\text { skaičius vie- } \\
\text { nam apdraus- } \\
\text { tajam [y] }\end{array}$ & $\begin{array}{c}\text { BVP, } \\
\text { tenkantis } \\
\text { vienam } \\
\text { gyventojui } \\
\text { (Lt) [x] }\end{array}$ & $\begin{array}{c}\text { Užsakymų } \\
\text { gaminti } \\
\text { produkciją } \\
\text { ir atlikti } \\
\text { darbus } \\
\text { indeksas } \\
\text { (proc.) }[\mathrm{x}]\end{array}$ & $\begin{array}{c}\text { Vidutiné } \\
\text { metiné } \\
\text { temperatūra } \\
\text { (C0) [x] }\end{array}$ & $\begin{array}{c}\text { Užimtų } \\
\text { gyventojų } \\
\text { skaičius } \\
\text { (tūkst.) [x] }\end{array}$ \\
\hline 2004 & 4,82 & 18654,42 & 86,83 & 6,7 & 1436,3 \\
\hline 2005 & 5,96 & 21791,22 & 100 & 6,8 & 1473,9 \\
\hline 2006 & 6,11 & 25452,44 & 137,77 & 7,3 & 1499 \\
\hline 2007 & 6,87 & 30708,84 & 165,82 & 7,75 & 1451,5 \\
\hline 2008 & 7,19 & 34994,39 & 168,92 & 8,2 & 1427,1 \\
\hline 2009 & 7 & 29097,33 & 101,86 & 7,1 & 1317,4 \\
\hline 2010 & 5,24 & 30890,3 & 113,22 & 6,2 & 1247,7 \\
\hline 2011 & 5,32 & 35300,31 & 129,50 & 7,6 & 1253,6 \\
\hline 2012 & 5,44 & 38066,71 & 151,41 & 6,7 & 1275,7 \\
\hline r & & 0,23 & 0,57 & 0,73 & 0,35 \\
\hline p reikšme & & 0,5 & 0,09 & 0,03 & 0,3 \\
\hline
\end{tabular}

$r$ - koreliacijos koeficientas

Šaltinis: autorių skaičiavimai, naudojant $\operatorname{VSDFV}^{18}$ ir Statistikos departamento duomenis ${ }^{19}$

Palyginus apmokètų dienų dèl ligos vienam apdraustajam skaičiaus ir bendrojo vidaus produkto, tenkančio vienam gyventojui litais, kitimą (žr. 2 lent.), nustatyta silpna ir nepatikima koreliacija $(\mathrm{r}=0,23 ; \mathrm{p}=0,5)$. Apmokètų laikinojo nedarbingumo dienų dèl ligų skaičiaus vienam apdraustajam ir užsakymų produkcijai gaminti ir darbams atlikti indekso kitimo palyginimas parodè, kad nustatyta vidutine statistiškai patikima koreliacija $(r=0,57 ; \mathrm{p}=0,09)$. Pakankamai stipri koreliacija buvo nustatyta tarp apmoketų laikinojo nedarbingumo dienų dèl ligų skaičiaus vienam apdraustajam ir vidutinès metinès temperatūros $(\mathrm{r}=0,73, \mathrm{p}=0,03)$.

Sunku komentuoti šias sąsajas. Stiprus ryšys egzistuoja tarp vidutinės metinès temperatūros ir apmokètų laikinojo nedarbingumo dienų dèl ligų skaičiaus vienam apdraustajam, tačiau negalime teigti, kad dèl vidutinès temperatūros didejjimo didejo ir sergamumas. Negali būti atmetama ir piktnaudžiavimo prielaida, kad esant geresniems, palankiems poilsiui orams dideja laikinojo nedarbin-

18 Supra note 12.

19 Statistikos departamento duomenys [interaktyvus]. [žiūrèta 2014-02-20]. <http://www.stat.gov.lt>. 
gumo piktnaudžiavimo atvejų. Užsakymų gaminti produkciją ir atlikti darbus indekso augimas galimai veikè darbo krūvio didèjimą, poilsio mažèjimą bei sergamumą, todèl tikètina, kad dèl šios priežasties egzistuoja vidutinis šio rodiklio ir laikinojo nedarbingumo ryšys. Atliktų duomenų analizė parodẻ, kad ryšys tarp dienų dèl ligų skaičiaus vienam apdraustajam ir bendrojo vidaus produkto bei užimtų gyventojų skaičiaus kitimo yra silpnas. Galimai bendras ekonomikos lygis ir darbo rinkos pokyčiai Lietuvoje nèra pagrindiniai veiksniai, nuo kurių priklauso laikinasis nedarbingumas. Neatmetama ir tai, jog šis rodiklis nèra jautrus nagrinejjamai situacijai vertinti.

\section{Visuomeninio lygmens veiksniai}

Visuomeniniam lygmeniui priskiriami su darbo aplinka bei bendruomene susiję veiksniai. Laikinojo nedarbingumo pokyčiams įtakos turi darbo aplinkos sąlygos, tokios kaip fiziniai pavojai ir monotonija, darbo užmokestis ir kontrolè. Be šių su darbo aplinka susijusių sąlygų, gyventojų sergamumą gali paveikti ir psichologiniai veiksniai, tokie kaip darbo kultūra - pasitenkinimas darbu bei bendruomenès ir šeimos kultūra. Šiam laikinojo nedarbingumo lygmeniui priskiriama geografinè bendruomenès padetis ir jos socialinis ekonominis lygis, kurị lemia gaunamos pajamos ir socialinè padètis. Svarbūs tokie veiksniai kaip bendruomeneje vyraujanti darbo rinka, sveikatos priežiūros paslaugų prieinamumas bei smurto lygis. Kaip ir nacionaliniam, visuomeniniam lygmeniui galime priskirti ir sveikatos priežiūros, ir socialinio draudimo praktinị organizavimą ${ }^{20}$.

3 lentelè. Visuomeninio lygmens veiksniai ir jų ryšys su laikinuoju nedarbingumu

\begin{tabular}{|c|c|c|c|c|c|}
\hline Metai & $\begin{array}{c}\text { Apmokètų } \\
\text { laikinojo nedar- } \\
\text { bingumo dienų } \\
\text { dèl ligų skaičius } \\
\text { vienam } \\
\text { apdraustajam } \\
{[y]}\end{array}$ & $\begin{array}{l}\text { Asmenys, } \\
\text { nukentejję } \\
\text { nuo nelai- } \\
\text { mingų atsiti- } \\
\text { kimų darbe } \\
\text { [x] }\end{array}$ & $\begin{array}{l}\text { Vidutinis } \\
\text { ménesinis } \\
\text { bruto darbo } \\
\text { užmokestis } \\
\text { (Lt) }[\mathrm{x}]\end{array}$ & $\begin{array}{l}\text { Vidutinès } \\
\text { disponuojamo- } \\
\text { sios pajamos } \\
\text { vienam namų } \\
\text { ùkio nariui per } \\
\text { ménesị }(\mathrm{Lt})[\mathrm{x}]\end{array}$ & $\begin{array}{l}\text { Sveikatos } \\
\text { priežiūros } \\
\text { istaigų } \\
\text { skaičius [x] }\end{array}$ \\
\hline 2006 & 6,11 & 3581 & 1495,7 & & 2849 \\
\hline 2007 & 6,87 & 3680 & 1802,4 & 952,1 & 2834 \\
\hline 2008 & 7,19 & 3328 & 2151,7 & 1133,2 & 2680 \\
\hline 2009 & 7 & 2093 & 2056 & 983,5 & 2820 \\
\hline 2010 & 5,24 & 2359 & 1988,1 & 894,2 & 2885 \\
\hline 2011 & 5,32 & 2721 & 2045,9 & 1016,5 & 2884 \\
\hline
\end{tabular}

20 Alexanderson, K., supra note 1, p. 241-249. 


\begin{tabular}{|c|c|c|c|c|c|}
\hline 2012 & 5,44 & 2897 & 2123,8 & & 3115 \\
\hline $\boldsymbol{r}$ & & 0,3 & 0,36 & 0,7 & $-0,7$ \\
\hline $\begin{array}{c}\boldsymbol{p} \\
\boldsymbol{r} \boldsymbol{e} \boldsymbol{k} \check{\boldsymbol{s}}- \\
\boldsymbol{m} \dot{\boldsymbol{e}}\end{array}$ & & 0,5 & 0,4 & 0,09 & 0,07 \\
\hline
\end{tabular}

$r$ - koreliacijos koeficientas

Šaltinis: autorių skaičiavimai, naudojant VSDFV ${ }^{21}$ ir Statistikos departamento duomenis ${ }^{22}$

Kaip vienai iš darbo aplinkos sąlygų - fizinių pavojų sąsajai su laikinuoju nedarbingumu išreikšti naudojome asmenų, nukentejusių nuo nelaimingų atsitikimų darbe, skaičiaus pokyčius. Tarp šių rodiklių nustatyta silpna koreliacija $(r=0,3)$. Apmokètų dienų dẻl ligos vienam apdraustajam skaičiaus ir vidutinio darbo užmokesčio ryšys yra silpnas ir nepatikimas $(\mathrm{r}=0,36, \mathrm{p}=0,4)$.

Vienas iš šeimos padètị bendruomeneje charakterizuojančių rodiklių yra namų ūkio disponuojamosios pajamos. Apmokètų laikinojo nedarbingumo dienų dẻl ligų skaičiaus vienam apdraustajam kitimo ir vidutinių disponuojamųjų pajamų vienam namų ūkio nariui per mėnesį kitimo palyginimas parodé, kad nustatyta koreliacija yra stipri $(\mathrm{r}=0,7 ; \mathrm{p}=0,09)$. Nedarbingumo didejjimui galimai įtakos turèjo vaikų sergamumas, siekis ilgiau rūpintis sergančiais vaikais.

Sveikatos priežiūros paslaugų prieinamumui charakterizuoti pasirinkome sveikatos priežiūros įstaigų šalyje skaičių. Palyginus apmokètų dienų dẻl ligos vienam apdraustajam skaičiaus kitimą ir sveikatos priežiūros įstaigų šalyje skaičiaus kitimą, nustatyta stipri koreliacija $(r=-0,7 ; \mathrm{p}=0,07)$. Tai tik patvirtina prielaidą, kad geresnis sveikatos priežiūros paslaugų prieinamumas bei gydymo efektyvumas mažina sergamumą bei trumpina laikinojo nedarbingumo laikotarpi.

\section{Individualaus lygmens veiksniai}

Paskutiniam laikinojo nedarbingumo lygmeniui priskiriami mažiausiai nuo kitų îtakos priklausantys veiksniai, todèl ir šių veiksnių kontrolè tampa sudètinga. Individualiam lygmeniui priskiriama asmeni charakterizuojantys veiksniai. Laikinasis nedarbingumas gali priklausyti nuo asmens gyvenimo būdo, išsilavinimo, šeiminès padèties bei santykių, asmeninių gebẻjimų, žalingų ịpročių, tokių kaip alkoholio ar narkotinių medžiagų vartojimas ar rūkymas, ir darbo bei poilsio laiko organizavimo. Be šių individualių savybių, svarbi asmens psichinė būkle bei motyvacija ir požiūris.

\footnotetext{
21 Supra note 12.

22 Supra note 19.
} 
4 lentelè. Individualaus lygmens veiksniai ir jų ryšys su laikinuoju nedarbingumu

\begin{tabular}{|c|c|c|c|c|}
\hline Metai & $\begin{array}{c}\text { Apmokètų laikinojo } \\
\text { nedarbingumo } \\
\text { dienų dèl ligu } \\
\text { skaičius vienam } \\
\text { apdraustajam [y] }\end{array}$ & $\begin{array}{c}\text { Santuokų } \\
\text { skaičius [x] }\end{array}$ & $\begin{array}{c}\text { Alkoholinių } \\
\text { gérimų suvarto- } \\
\text { jimas, tenkantis } \\
\text { vienam gyven- } \\
\text { tojui (litrais) [x] }\end{array}$ & $\begin{array}{c}\text { Visuomenès } \\
\text { dalis, igijusi } \\
\text { aukštaji išsilavi- } \\
\text { nimą (proc.)[x] }\end{array}$ \\
\hline 2004 & 4,82 & 1594 & 10,1 & 65 \\
\hline 2005 & 5,96 & 1662 & 10,4 & 68,5 \\
\hline 2006 & 6,11 & 1771 & 11,1 & 69 \\
\hline 2007 & 6,87 & 1922 & 11,7 & 70,9 \\
\hline 2008 & 7,19 & 2005 & 11,8 & 73,8 \\
\hline 2009 & 7 & 1712 & 11,1 & 71,5 \\
\hline 2010 & 5,24 & 1557 & 11,6 & 69,3 \\
\hline 2011 & 5,32 & 1602 & 12,7 & 65,9 \\
\hline 2012 & 5,44 & 1722 & 13 & 61,2 \\
\hline r & & 0,83 & 0,17 & 0,79 \\
\hline p reikš- & & 0,006 & 0,6 & 0,01 \\
\hline mé & & & & \\
\hline$r-k$
\end{tabular}

$r$ - koreliacijos koeficientas,

Šaltinis: autorių skaičiavimai, naudojant $\mathrm{VSDFV}^{23}$ ir Lietuvos statistikos departamento duomenis ${ }^{24}$

Siekdami nustatyti ryši tarp šeiminès padèties ir laikinojo nedarbingumo skaičiavimams naudojome rodiklį, nurodanti santuokų skaičiaus kitimą. Analizė parodé, jog ryšys tarp rodiklių pakankamai stiprus ir patikimas $(r=0,83 ; \mathrm{p}=0,006)$.

Alkoholio vartojimas Lietuvoje yra vienas iš plačiai paplitusių žalingiausių ipročių, reikalaujančių visuomenès, o kartu ir politikos dèmesio. Apmokètų laikinojo nedarbingumo dienų dèl ligų skaičiaus vienam apdraustajam ir absoliutaus alkoholio suvartojimo vienam gyventojui rodiklių palyginimas parodé, kad nustatyta labai silpna ir nepatikima koreliacija $(r=0,17 ; \mathrm{p}=0,6)$. Asmenys, kurie dèl traumos kreipèsi ị sveikatos priežiūros ịstaigą būdami neblaivūs arba kurių laikinojo nedarbingumo priežastis buvo piktnaudžiavimas alkoholiu, neturi teisès gauti laikinojo nedarbingumo pažymejjimą, kuris yra pagrindas gauti išmoką. Galimai tai turèjo įtakos tyrimo rezultatams.

\footnotetext{
23 Supra note 12.

24 Supra note 19.
} 
Išsilavinimas - tai vienas iš elgesio korekcijos stimulų. Nagrinėjant laikinojo nedarbingumo trukmès ir visuomenès dalies, igijusios aukštąji išsilavinimą, sąsajas, nustatyta stipri ir patikima koreliacija $(r=0,79, \mathrm{p}=0,01)$.

\section{Apibendrinimas ir išvados}

K. Alexandersono pasiūlytoje metodikoje yra minima daug veiksnių, kurie turi reikšmès laikinojo nedarbingumo trukmei. Tačiau analizuojant viešai skelbiamus duomenis Lietuvoje pavyko nustatyti tik dalị veiksnius charakterizuojančių rodiklių. Antra vertus, pasirinktas neaukštas reikšmingumo lygmuo. Tai, be abejo, apriboja tyrimo rezultatų reikšmę. Tačiau gauti rezultatai gali suteikti naudingos informacijos socialinès politikos formuotojams, vykdytojams bei darbdaviams gerinant laikinojo nedarbingumo kontrolę Lietuvoje, numatant išsamesnių mokslinių tyrimų šioje srityje kryptis.

1. Nacionaliniu lygmeniu apžvelgus laikinojo nedarbingumo trukmés pokyčius 1991-2012 m. ir nedarbingumo kompensavimo teisinio reglamentavimo kitimus, nustatytos tokios galimos šiu dviejų veiksniu sąsajos. Laikotarpiu nuo $1991 \mathrm{~m}$. iki 1995 m., esant asmeniui nepalankiam darbingumo kompensavimo mechanizmui, kai sumažintos išmokos už tris pirmas dienas ir jų mokèjimo ịpareigojimas perleistas darbdaviui, laikinojo nedarbingumo trukmé mažèjo. Nuo $2000 \mathrm{~m}$. iki $2004 \mathrm{~m}$ pastebimas nežymus laikinojo nedarbingumo didejjimas. Šiuo laikotarpiu igyvendintos laikinojo nedarbingumo kompensavimo reformos: sumažintos ilgesnių laikinojo nedarbingumo periodų garantijos (nuo 100 iki 85 procentų), beveik išnyko ribos tarp ilgalaikių, vidutinès trukmès ir trumpalaikių nedarbingumų - nuo trečios dienos mokama išmoka sudarẻ 85 procentų darbo užmokesčio. Dar vienas nacionalinio lygmens neigiamos priklausomybès veiksnys, turèjęs ịtakos laikinajam nedarbingumui - vidutinès metinès temperatūros pokyčiai.

2. Visuomeniniame lygmenyje iš keturių nagrinètų veiksnių patikimas ryšys buvo nustatytas su vidutinemis disponuojamomis pajamomis vienam namų ūkio nariui ir sveikatos priežiūros ịstaigų skaičiumi. Galimai geresnis sveikatos priežiūros paslaugų prieinamumas, tinkamas ir efektyvus gydymas mažina sergamumą ir turi ịtakos laikinojo nedarbingumo mažejimui.

3. Individualiame lygmenyje iš trijų nagrinètų rodiklių teigiamos patikimos laikinojo nedarbingumo sąsajos buvo nustatytos su šeimine padètimi (santuokų skaičiumi) ir išsilavinimu (visuomenès dalimi, tgijusia aukštąji išsilavinimą). 


\section{Literatūra}

1. Alexanderson, K. Sickness absence: a review of performed studies with focused on levels of exposure and theories utilized. Scandinavian Journal of Social Medicine. 1998, 4( 26): 241-249.

2. Bartkus, A. Senatvés pensijų ir laikinojo nedarbingumo išmoku finansinio tvarumo analize. Daktaro disertacija. Vilnius: Vilniaus universitetas. 2009, p. 140-142.

3. Bartkus, E. V. Smulkaus ir vidutinio verslo plètros prognozės Lietuvoje ekonominès krizès pradžioje. Ekonomika ir vadyba. 2010, 15.

4. Bieliauskaitè, J. Solidarumo vaidmuo socialinèje teisinèje valstybèje. Socialiniu mokslu studijos. 2009, 1(1): 79-94.

5. Earle, A.; Ayanian, J. Z.; Heymann, J. Work resumption after newly diagnosed coronary heart disease: findings on the importance of paid leave. Journal of Women's Health. 2006, 4(15): 430-441.

6. Guogis, A. Dèl Socialinès politikos modelio. Politologija. 2002, 4 (28): 75-94.

7. Guogis, A., et al. Lietuvos politiniu partiju samprata apie socialinę apsauga. Vilnius: Eugrimas, 2000.

8. Hansen, H. T.; Ingebrigtsen, T. Social Class and Sickness Absence in Norway. Acta Sociologica. 2008, 51: 309-327 [interaktyvus]. [žiūrèta 2013-10-12]. <http://asj. sagepub.com.skaitykla.mruni.eu/content/51/4/309.full.pdf+html>.

9. Lietuvos Respublikos valstybinio socialinio draudimo îstatymas. Valstybès žinios. 1991, Nr. 17-447; 2004, Nr. IX-2535, Nr. 171-6295.

10. Predkelienè, R. Asmens poreikiu samprata, klasifikavimas ir atspindëjimas socialinès apsaugos teiseje. Magistro darbas. Vilnius: Mykolo Romerio universitetas, 2007.

Internetiniai šaltiniai

11. Valstybinis socialinis draudimas: statistiniai duomenys [interaktyvus]. 2012 [žiūrèta 2013-12-16]. <http://www.sodra.lt/get.php?f.24143>.

12. VSDFV pranešimai spaudai [interaktyvus]. [žiūrèta 2013-10-12]. <http://www.sodra. lt/index.php?cid=182\&new_id=24609\&page_nr=>.

13. Lietuvos Respublikos Seimo aktualios teisès aktų redakcijos laikotarpiu nuo $1991 \mathrm{~m}$. iki 2010 m. [interaktyvus]. [žiūrèta 2013-12-16-2014-03-02]. <http://www.lrs.lt/>.

14. Statistikos departamento duomenys [interaktyvus]. [žiūrèta 2014-02-20]. <http:// www.stat.gov.lt $>$.

\section{Factors that Influence Absence from Work due to Illness in Lithuania}

\section{Aušra Survilaitè}

State Social Insurance Fund Board, Vilnius Branch, Lithuania

Aldona Gaižauskienè

University of Applied Science, Mykolas Romeris University, Lithuania

Summary. The aim of the paper is to determine factors that influence absence from work due to illness in Lithuania during 1991-2012, according to the method proposed by K. Alexanderson (1998) on national, public and individual levels. The 
data were taken from the State Social Insurance Fund Board and the Lithuanian Department of Statistics.

On national level, absence from work due to illness was related to changes in the legal framework. Analysis of the data showed that the changes in absence from work due to illness is affected by employer obligations for sickness benefits, the state guarantees replacement and the insurance additional requirements, such as introduction of membership period. Another factor, which particularly affects absence from work, is the average annual temperature. On public level, household income and number of health care institutions had correlation with absence from work. On individual level, the significant correlation was found with education and marital status.

Determination of the factors, which affect absence from work due to illness in Lithuania, presents the control system recommendations for improvements, provides useful information for control policy makers, practitioners and employers.

Keywords: absence from work due to illness, social insurance, national factors, public factors, individual factors.

Aldona Gaižauskienė, Vilniaus kolegija, Mykolo Romerio universitetas, docenté, biomedicinos mokslų daktarè.

Aldona Gaižauskienė, University of Applied Science, Mykolas Romeris University, Assoc. Professor, PhD.

Aušra Survilaitė, Valstybinio socialinio draudimo fondo valdybos Vilniaus skyrius, Pašalpų ir nedarbingumo kontrolès skyriaus vyr. specialistė.

Aušra Survilaitė, State Social Insurance Fund Board, Vilnius Branch, Benefit and Disability Control Division, Chief Specialist. 